\title{
PENGELOLAAN SUMBERDAYA IKAN BILIH (Mystacoleucus padangensis) INTRODUKSI DI DANAU TOBA, SUMATERA UTARA
}

\author{
Endi Setiadi Kartamihardja \\ Peneliti pada Pusat Riset Perikanan Tangkap, Ancol-Jakarta \\ Teregistrasi I tanggal: 6 Pebruari 2007; Diterima setelah perbaikan tanggal: 26 Maret 2008; \\ Disetujui terbit tanggal: 25 April 2008
}

\begin{abstract}
ABSTRAK
Spesies endemik Danau Singkarak, ikan bilih (Mystacoleucus padangensis) 2.840 ekor ukuran panjang total 4,1-5,7cm dengan bobot 0,9-1,5 g per ekor diintroduksikan ke Danau Toba (112.000 ha) pada tanggal 3 Januari 2003. Ikan bilih tumbuh pesat dan memijah di muara-muara sungai yang masuk danau. Pada tahun 2005, hasil tangkapan ikan bilih mencapai 653,6 ton (14\% dari total hasil tangkapan) dan pada tahun 2008 diperkirakan meningkat menjadi 1.755 ton. Untuk meningkatkan hasil tangkapan ikan bilih secara optimal dan lestari diperlukan cara pengelolaan yang meliputi penetapan suaka perikanan, pengaturan alat tangkap, penanganan hasil tangkapan, pengembangan kelembagaan dan peraturan pengelolaan, pengembangan pengelolaan secara bersama, dan monitoring serta evaluasi. Ikan bilih dapat dijadikan kandidat ikan tebaran untuk danau-danau yang memiliki karakteristik limnologi yang serupa dengan Danau Toba atau Singkarak dan dilakukan dengan pendekatan kehatihatian.
\end{abstract}

KATAKUNCl: introduksi ikan, pengelolaan perikanan, ikan bilih, spesies endemik, Danau Toba

ABSTRACT: Resources management of the bilih (Mystacoleucus padangensis) introduced in Lake Toba, North Sumatra. By: Endi Setiadi Kartamihardja

An endemic species of Singkarak Lake, bilih (Mystacoleucus padangensis) of 2,840 fingerlings having $4.1-5.7 \mathrm{~cm}$ in total length and 0.9-1.5 g in weight, were introduced to Toba Lake (112,000 ha) at 3 January 2003. The fish grew fast and spawned in the bank of rivers entering the lake. In 2005, the fish could be yielded at 653,6 ton (14\% of the total fish catch) and in 2008 it was estimated to be 1.755 ton. To increase the the fish yield optimally and sustainably, some management measures of the resources should be applied i.e., establishment of the bilih reserve area, regulation of fishing gears, development of fish product diversification, development of management institution and fisheries regulation, development of comanagement, and monitoring and evaluation. The bilih can be promoted as a candidate of fish introduction for other lakes having similar limnological characteristics with Toba Lake as well as Singkarak. Even thought the bilih introduction should be done with a precautionary approach.

KEYWORDS: fish introduction, fisheries management, bilih, endemic species, Lake Toba 


\section{PENDAHULUAN}

Ikan bilih (Mystacoleucus padangensis) adalah ikan endemik yang hidup di Danau Singkarak, Sumatera Barat. Sebagai ikan endemik, ikan bilih hidup dalam geografis yang terbatas sehingga di dunia hanya ditemukan di Danau Singkarak (Kottelat et al., 1993). Oleh karena itu, Danau Singkarak merupakan habitat asli ikan bilih.

Seperti ikan endemik pada umumnya, ikan bilih juga rentan terhadap kepunahan akibat kerusakkan habitat dan eksploitasi yang intensif. Di Danau Singkarak, ikan bilih merupakan hasil tangkapan utama di samping jenis-jenis ikan ekonomis lainnya, seperti asang (Osteochilus brachynopterus), sasau (Hampala ampalong), dan turik (Cyclocheilichthys de Zwani). Pada tahun 2002, sekitar 90\% dari hasil tangkapan nelayan di Danau Singkarak adalah ikan bilih. Harga ikan bilih yang ekonomis tinggi menjadikan ikan ini sebagai komoditas ekspor ke negara jiran (Malaysia dan Singapura) dalam bentuk kering. Namun, sejak tahun 2000, hasil tangkapan ikan bilih di danau ini terus menurun dan ukuran ikan pun mengecil, hanya mencapai panjang total $9,0 \mathrm{~cm}$ (Purnomo et al., 2003). Padahal sebelum tahun 1990, ikan bilih yang tertangkap dapat mencapai panjang total 19,5 cm (Purnomo et al., 1992).

Introduksi ikan (fish introduction atau transplantation) adalah upaya memindahkan atau menebarkan ikan dari suatu perairan ke perairan lain di mana jenis ikan yang ditebarkan semula tidak terdapat di perairan tersebut (Cowx, 1994; 1999). Dengan demikian, introduksi ikan bilih berarti memindahkan ikan tersebut dari habitat aslinya di Danau Singkarak ke habitat yang baru di Danau Toba. Pada awalnya, ikan bilih tersebut tidak terdapat di Danau Toba meskipun masyarakat setempat mengatakan sebagai ikan porapora (Puntius binotatus), sejenis ikan yang sebelum tahun 1990-an banyak terdapat di danau ini dan mempunyai bentuk badan yang mirip dengan ikan bilih (Kartamihardja, 1993). Introduksi ikan bilih ke Danau Toba yang dilakukan pada tanggal 3 Januari 2003 menunjukkan pertumbuhan dan perkembangan yang baik sehingga berdampak positif terhadap peningkatan hasil tangkapan ikan di danau ini. Dewasa ini, keberhasilan introduksi ikan bilih tersebut belum diikuti dengan pelaksanaan pengelolaannya sehingga dikhawatirkan eksploitasi ikan bilih yang telah dilakukan sejak tahun 2005 tidak memberikan hasil tangkapan yang optimal dan mengancam kelestariannya seperti yang terjadi di Danau Singkarak.

\section{SIKLUS HIDUP DAN INTRODUKSI IKAN BILIH DI DANAU TOBA}

\section{Siklus Hidup Ikan Bilih}

Ikan bilih melakukan reproduksi atau pemijahan dengan cara menyongsong aliran air di sungai yang bermuara di danau. Induk jantan dan betina beruaya ke arah sungai yang mempunyai kecepatan arus air 0,30,6 m per detik dan kedalaman air 10-20 $\mathrm{cm}$. Habitat pemijahan ikan bilih adalah perairan sungai yang jernih dengan suhu air relatif rendah, berkisar $24,0-26,0^{\circ} \mathrm{C}$, dan dasar sungai yang berbatu kerikil dan atau berpasir. Dalam hal ini, faktor lingkungan yang mempengaruhi pemijahan ikan bilih adalah arus air dan substrat dasar. Ikan bilih menuju ke daerah pemijahan menggunakan orientasi visual dan naluri. Sesampainya di habitat pemijahan tersebut, ikan bilih betina melepaskan telur dan bersamaan dengan itu juga ikan jantan melepaskan sperma untuk membuahi telur tersebut. Telur ikan bilih yang telah dibuahi berwarna transparan dan tenggelam di dasar sungai (di kerikil atau pasir) untuk kemudian hanyut terbawa 
arus air masuk ke danau. Telur-telur tersebut akan menetas di danau sekitar 19 jam setelah dibuahi pada suhu air 27,0$28,0{ }^{\circ} \mathrm{C}$ dan larva berkembang di danau sampai dewasa.

Ikan bilih memijah setiap hari, sepanjang tahun, mulai dari sore-pagi hari. Puncak pemijahan ikan bilih terjadi pada pagi hari mulai dari jam 5.00-9.00, seperti diperlihatkan dengan banyaknya telur yang dilepaskan. Pemijahan ikan bilih bersifat parsial, yakni telur yang telah matang kelamin tidak dikeluarkan sekaligus tetapi hanya sebagian dalam satu kali periode pemijahan.

\section{Introduksi Ikan Bilih}

Introduksi ikan bilih ke Danau Toba dilakukan melalui proses penelitian yang cukup panjang. Kegiatan penelitian yang pertama dilakukan adalah mempelajari tingkah laku ikan bilih di habitat aslinya, (Danau Singkarak) yang meliputi aspek makanan dan kebiasaan makan, pertumbuhan, dan reproduksi serta karakteristik habitat yang diperlukan, baik habitat pemakanan, asuhan, dan pemijahan. Bersamaan dengan penelitian tersebut dilakukan pula studi mengenai karakteristik habitat, ketersediaan makanan, dan struktur populasi ikan serta relung ekologi di Danau Toba. Penelitian yang dilakukan di Danau Toba terutama dimaksudkan agar ikan bilih dapat menempati habitat yang sesuai bagi kehidupan, makanan alami tersedia, dan dapat mengisi relung ekologis yang kosong sehingga tidak berkompetisi dan merugikan jenis ikan asli yang hidup di Danau Toba.

Tahapan berikut adalah bagaimana mempersiapkan ketersediaan benih ikan bilih yang akan dintroduksikan. Pada waktu itu, teknologi pembenihan ikan bilih belum berkembang sehingga benih ikan bilih yang dihasilkan dari pembenihan tidak mungkin tersedia. Di samping itu, meskipun pembenihan sudah berhasil, namun untuk menyediakan benih yang cukup banyak belum efisien, biaya produksi benih tinggi. Oleh karena itu, untuk keperluan penyediaan benih ikan bilih diputuskan diambil dari hasil tangkapan di Danau Singkarak.

Upaya penangkapan ikan bilih dilakukan dengan alat tangkap yang memungkinkan ikan tersebut tertangkap hidup dan tidak melukai. Alat tangkap alahan adalah salah satu alat tangkap yang memungkinkan untuk maksud tersebut. Namun, pada saat akan dilakukan pengumpulan benih, semua alat alahan tidak beroperasi karena permukaan air Danau Singkarak tinggi, merendam seluruh alahan. Untuk keperluan tersebut diputuskan penangkapan ikan dilakukan dengan menggunakan anco (lift net) yang dibuat dari bahan waring berukuran panjang $x$ lebar: 1,5x1,5 m dengan bingkai terbuat dari bambu. Anco dipasang di pinggir pantai Danau Singkarak dekat Unit Pelaksana Teknis Perikanan Perairan Umum atau Hatchery Singkarak. Pengangkatan alat tangkap anco dilakukan setiap jam.

Sebanyak 3.400 ekor ikan bilih hasil tangkapan, berukuran panjang total 4,1$5,7 \mathrm{~cm}$ dengan bobot 0,9-1,5 g per ekor, dikemas dalam kantong plastik untuk kemudian diangkut melalui jalan darat menuju Parapat di Danau Toba yang ditempuh sekitar 18 jam. Proses adaptasi dengan kondisi air Danau Toba dilakukan dalam keramba jaring apung.

Pada tanggal 3 Januari 2003, ikan bilih ditebarkan di Daerah Parapat dan Ajibata di Danau Toba. Dari jumlah ikan bilih yang dibawa 3.400 ekor dapat hidup dan ditebarkan 2.840 ekor karena mati 25\%. Sebanyak 50 ekor ikan bilih tetap dipelihara 
dalam satu karamba jaring untuk mempelajari perkembangannya di Danau Toba.

\section{PERKEMBANGAN SUMBER DAYA IKAN BILIH}

\section{Pertumbuhan Populasi Ikan Bilih}

Evaluasi perkembangan ikan bilih di Danau Toba pertama kali dilakukan pada tahun 2005, dua tahun setelah ikan bilih ditebarkan. Hasil monitoring menunjukkan bahwa ikan bilih dapat berkembang dan tumbuh pesat serta melakukan reproduksi di muara-muara sungai yang masuk ke Danau Toba. Distribusi atau penyebaran populasi ikan bilih meliputi seluruh perairan Danau Toba, bahkan ditemukan pula di daerah pelagis dan limnetik danau yang selama ini sangat sedikit sekali dihuni oleh jenis ikan lainnya. Jenis-jenis ikan lain yang hidup di Danau Toba, yakni ikan mujair (Oreochromis mossambicus), nila (O. niloticus), nilem (Osteochillus haselti), mas (Cyprinus carpio), dan betutu (Oxyleotris marmorata) hanya mampu memanfaatkan daerah litoral danau (Purnomo et al., 2005). Masyarakat sekitar
Danau Toba dan Sumatera Utara pada umumnya mengatakan ikan bilih sebagai ikan pora-pora karena sejak tahun 1990-an, ikan tersebut yang mirip ikan bilih dan hidup di Danau Toba tidak pernah tertangkap lagi (Kartamihardja, 1993).

Pemijahan ikan bilih terjadi hampir di seluruh aliran sungai yang bermuara di danau dan habitat pemijahannya terbesar terdapat di Sungai Sipiso-piso (Tongging), Sungai Sipangolu (Bakara), Sungai Naborsahan (Ajibata), Sungai Sisodang (Tomok), serta sungai-sungai kecil yang termasuk di Daerah Silalahi I dan II dekat Pembangkit Listrik Tenaga Air Renum (Kartamihardja \& Purnomo, 2006; Purnomo et al., 2006) (Gambar 1).

Sungai yang masuk Danau Toba tercatat 152 buah sungai dan 212 anak sungai di mana 71 buah sungai selalu berair sepanjang tahun. Sungai yang masuk ke danau tersebut pada umumnya berair jernih, berbatu, dan atau berpasir dengan suhu air $25,0-27,0^{\circ} \mathrm{C}$ sehingga sangat sesuai sebagai habitat yang ideal dan sangat sesuai serta dibutuhkan oleh ikan bilih untuk melakukan reproduksi.

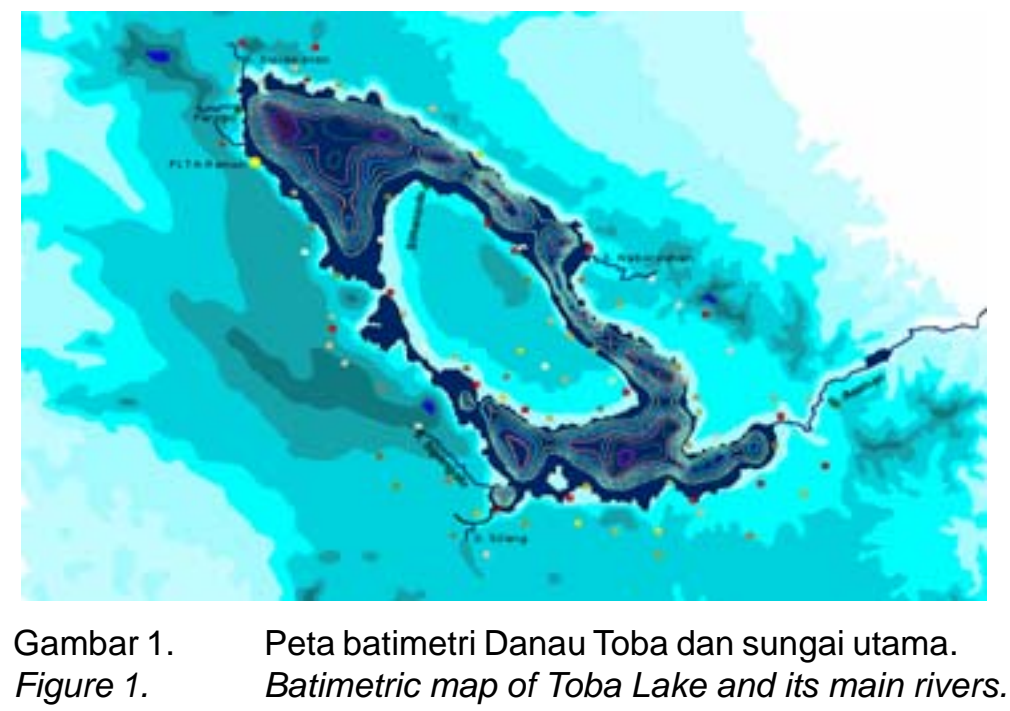




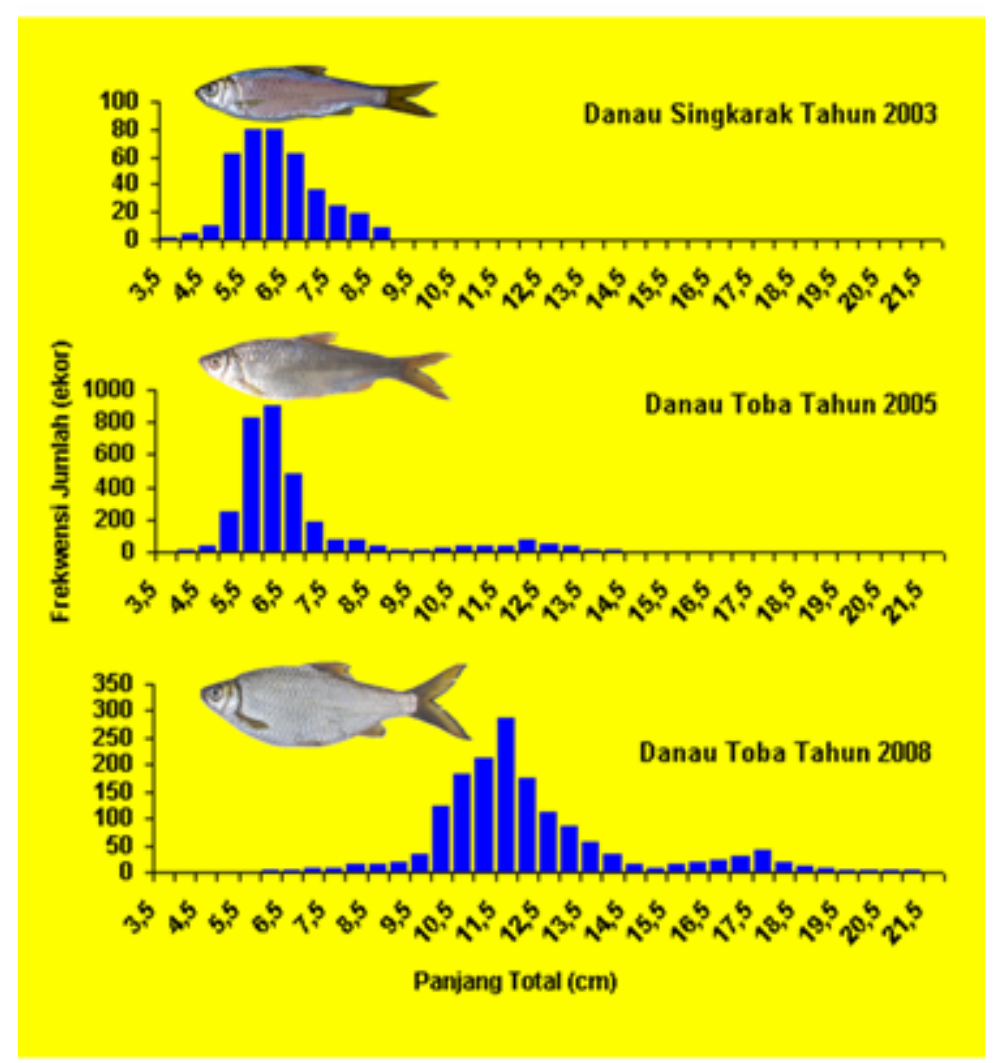

Gambar 2. Distribusi ukuran panjang total ikan bilih yang tertangkap di Danau Singkarak tahun 2003 dan Danau Toba, tahun 2005 dan 2008.

Figure 2. $\quad$ Length frequency distribution of bilih caught at Singkarak Lake in 2003 and Toba Lake in 2005 and 2008.

Ukuran panjang ikan bilih yang tertangkap juga jauh lebih besar dari ratarata ukuran ikan tersebut di habitat aslinya (Danau Singkarak). Pada tahun 2003, ratarata panjang total ikan bilih di Danau Singkarak adalah $6,5 \mathrm{~cm}$ (Purnomo et al., 2003). Pada tahun 2005, di Danau Toba rata-rata ukuran panjang ikan bilih yang tertangkap 6,5 dan $12,5 \mathrm{~cm}$, namun pada tahun 2008 rata-rata ukuran panjang total menjadi 13,5 dan 18,5 cm (Purnomo et al., 2005; Kartamihardja \& Sarnita, 2008 in press) (Gambar 2).

Ikan bilih ukuran rata-rata panjang total $13,5 \mathrm{~cm}$ tertangkap dengan jaring insang ukuran mata jaring 1,25 inci, sedangkan ukuran panjang total $18,5 \mathrm{~cm}$ tertangkap dengan jaring insang ukuran mata jaring 1,5 inci. Hal ini menandakan bahwa makanan alami yang tersedia cukup memadai dan mungkin tingkat eksploitasi populasi ikan bilih juga belum intensif.

\section{Kontribusi Ikan Bilih terhadap Hasil Tangkapan dan Pendapatan Nelayan}

Pada tahun 2005, hasil tangkapan ikan bilih yang dicatat oleh enumerator di beberapa tempat pendaratan ikan menunjukkan hasil tangkapan 653,6 ton atau $14,6 \%$ dari total hasil tangkapan ikan 
4.462 ton (Gambar 3). Sedangkan total potensi produksi ikan yang ditaksir berdasarkan pada produktivitas primer perairan berkisar 2.519-7.309 ton per tahun. Hasil tangkapan ikan bilih tersebut berada pada urutan ketiga setelah ikan mujair dan nila. Dengan rata-rata harga jual ikan Rp.6.000/kg, diperkirakan nilai hasil tangkapan pada tahun 2005 mencapai Rp.3,9 milyar. Pada tahun tersebut, dampak hasil tangkapan ikan bilih terhadap pendapatan nelayan diperkirakan mulai dirasakan meskipun belum secara nyata dinikmati oleh banyak anggota masyarakat. Pada periode tersebut aktivitas penangkapan ikan bilih mulai meningkat.

Berdasarkan pada hasil wawancara dengan beberapa nelayan dan pedagang ikan pada bulan April 2008 diperoleh informasi bahwa aktivitas penangkapan ikan bilih mulai tinggi pada tahun 2007. Pada saat itu, pedagang pengumpul dari Kota Pekanbaru, Riau mulai berdatangan dan bersedia menampung ikan hasil tangkapan nelayan di beberapa sentra produksi, seperti di Pasar Tigaraja, Parapat, Tongging, Bakara di Porsea, dan Balige.

Hasil tangkapan, total tangkapan, dan harga jual ikan bilih serta perkiraan pendapatan kotor nelayan di keempat tempat pendaratan ikan tercantum pada Tabel 1. Di Pasar Tigaraja, Parapat setiap hari didaratkan 1,5-2 ton ikan bilih yang dijual ke pedagang pengumpul untuk kemudian diangkut dalam bentuk segar menggunakan kotak plastik kapasitas 50$60 \mathrm{~kg}$ ke Pekanbaru. Setiap tiga hari sekali, di tempat yang sama, pedagang pengumpul dari Padang juga rata-rata mengangkut sekitar 2-3 ton ikan bilih. Rata-rata harga ikan bilih yang dibeli pedagang pengumpul dari nelayan di sini paling tinggi yaitu Rp.4.000/kg, jika dibandingkan dengan harga jual di tempat pendaratan lain. Pendapatan kotor nelayan di sekitar Parapat ini berkisar Rp.200.000-300.000 per hari atau sekitar Rp.6-9,6 juta per bulan.

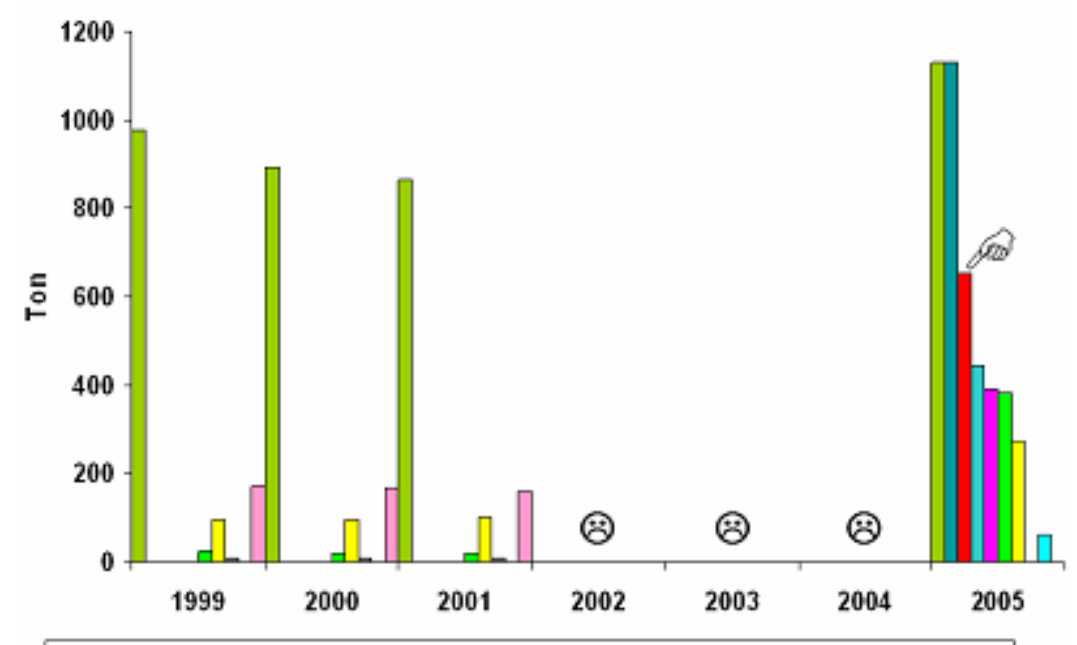

$\square$ Mujair $\square$ Mila $\square$ Bilih $\square$ Gabus $₫$ Betutu $\square$ Lele $\square$ Mas $\square$ Tawes $\square$ Betok $\square$ Lainnya

Gambar 3. Hasil tangkapan Ikan di Danau Toba periode 1999-2005 (Purnomo et al., 2005).

Figure 3. $\quad$ Fish catch at Lake Toba in 1999-2005 (Purnomo et al., 2005). 
Tabel 1.

Hasil tangkapan, total tangkapan, dan harga jual ikan bilih serta perkiraan pendapatan kotor nelayan di 4 pendaratan ikan, tahun 2008

Table 1. Range of bilih fish catch and its selling price and estimated fisher income at four landing places in 2008

\begin{tabular}{|c|c|c|c|c|}
\hline \multirow{2}{*}{ Parameter/Parameters } & \multicolumn{4}{|c|}{ Tempat pendaratan ikan/Fish landing places } \\
\hline & Parapat & Tongging & Porsea & Balige \\
\hline $\begin{array}{l}\text { Hasil tangkapan (kg/nel/hr) } \\
\text { Fish catch (kg/fisher/day) }\end{array}$ & $50-80$ & $40-60$ & $10-30$ & $20-30$ \\
\hline $\begin{array}{l}\text { Total tangkapan (ton/hr)/ } \\
\text { Total fish catch (ton/day) }\end{array}$ & $1,5-2,0$ & $2,0-2,5$ & $0,5-1,0$ & $1,5-2,0$ \\
\hline $\begin{array}{l}\text { Harga jual ke pengumpul }(\mathrm{Rp} / \mathrm{kg}) / \\
\text { Selling price to middle trader }(\mathrm{Rp} / \mathrm{kg})\end{array}$ & 4000 & 3000 & 2000 & 2500 \\
\hline $\begin{array}{l}\text { Pendapatan (ribu Rp/nel/hr)/ } \\
\text { Income (thousand Rp/fishers/day) }\end{array}$ & $200-320$ & $120-180$ & $20-60$ & $50-75$ \\
\hline Harga eceran $(\mathrm{Rp} / \mathrm{kg}) /$ Price retail $(\mathrm{Rp} / \mathrm{kg})$ & 6000 & 6000 & 5000 & 6000 \\
\hline
\end{tabular}

Keterangan: Harga eceran = harga jual pedagang ikan di pasa

Remarks: Price retail : selling price in the marke

Di Tongging, total ikan bilih yang didaratkan berkisar 2,0-2,5 ton per hari. Secara rutin, tiap hari pedagang pengumpul dari Pekanbaru mengangkut ikan bilih tersebut. Hasil tangkapan ikan bilih di kawasan ini berkisar 40-60 kg per nelayan per hari. Harga jual ikan bilih ke pedagang pengumpul adalah Rp.3.000 per $\mathrm{kg}$, sehingga secara kasar pendapatan kotor setiap nelayan berkisar Rp.120.000180.000 per hari atau Rp.3,6-5,4 juta per bulan. Harga jual ikan bilih ke pedagang pengumpul memang jauh lebih rendah jika dibandingkan harga eceran ikan bilih yang dijual ke masyarakat sekitar Rp.6.000 per kg. Namun, berdasarkan pada hasil wawancara dengan beberapa nelayan mengatakan bahwa dengan menjual ke pedagang pengumpul, ikan bilih hasil tangkapan dapat terjual cepat. Dengan ada ikan bilih, para nelayan sangat bersyukur, karena kehidupan perekonomian yang selama ini terpuruk dapat bangkit kembali.

Di Porsea, terdapat sekitar 20 orang nelayan yang semula petani. Meskipun harga jual ikan bilih ke pedagang pengumpul di daerah ini yang terendah, yakni Rp.2.000 per $\mathrm{kg}$, namun mereka sangat beruntung dengan kehadiran ikan bilih. Alasannya beralih profesi adalah karena usaha tani membutuhkan modal yang besar terutama dengan kenaikan harga pupuk dan obatobatan di samping bertani memerlukan curahan tenaga yang jauh lebih besar. Selama ini marjin keuntungan yang diperoleh dari bertani sangat minim, malahan sering merugi. Berusaha sebagai nelayan hanya membutuhkan curahan tenaga yang kecil, yaitu memasang jaring pada sore hari dan mengangkat pada pagi keesokan hari. Di samping itu, modal yang diperlukan juga relatif murah, hanya pengadaan jaring insang dan perlengkapannya. Untuk 10 piece jaring hanya diperlukan biaya Rp.750.000 yang dapat bertahan sampai 8 bulan. Perahu yang digunakan juga tanpa motor dan harganya berkisar Rp.500.000-750.000. Rata-rata pendapatan kotor nelayan di kawasan ini berkisar Rp.20.00-60.000 per hari atau Rp.600.000-1.800.000 per bulan. Pendapatan ini dirasakan jauh lebih besar jika dibandingkan dari hasil usaha tani. Dari jumlah nelayan 20 orang dapat dihasilkan ikan bilih 0,5-1,0 ton per hari yang dijual ke pedagang pengumpul di Porsea. Kemudian pedagang pengumpul menjual ke Pekanbaru dalam keadaan segar. 
Tabel2. Prakiraan total hasil tangkapan ikan bilih di empat pendaratan ikan selama tahun 2008

Table 2. Estimated total bilih catch at four landing places in 2008

\begin{tabular}{lcccc}
\hline $\begin{array}{c}\text { Tempat } \\
\text { pendaratan/ } \\
\text { Landing places }\end{array}$ & $\begin{array}{c}\text { Rata-rata } \\
\text { Tangkapan } \\
\text { (ton/hr)/ } \\
\text { Average catch } \\
\text { (ton/day) }\end{array}$ & $\begin{array}{c}\text { Rata-rata tangkapan } \\
\text { bulan gelap (ton/15 hr)/I } \\
\text { Average catch during } \\
\text { dark moon (ton/15 days) }\end{array}$ & $\begin{array}{c}\text { Rata-rata tangkapan } \\
\text { bulan terang (ton/15 hr)/I } \\
\text { Average catch during } \\
\text { light moon (ton/day) }\end{array}$ & $\begin{array}{c}\text { Prakiraan total } \\
\text { tangkapan (ton/th)/ } \\
\text { Estimated total } \\
\text { catch (ton/yr) }\end{array}$ \\
\hline Parapat & 1,75 & 26,25 & 13,125 & 472,5 \\
Tongging & 2,25 & 33,75 & 16,875 & 607,5 \\
Porsea & 0,75 & 11,25 & 5,625 & 202,5 \\
Balige & 1,75 & 26,25 & 13,125 & 472,5 \\
\hline Total & $\mathbf{6 , 5}$ & $\mathbf{9 7 , 5}$ & $\mathbf{4 8 , 7 5}$ & $\mathbf{1 . 7 5 5}$ \\
\hline
\end{tabular}

Di Balige, total hasil tangkapan ikan bilih yang didaratkan berkisar 1,5-2,0 ton per hari. Ikan tersebut dijual ke pedagang pengumpul dengan harga Rp.2.500 per kg. Dengan kisaran hasil tangkapan $20-30 \mathrm{~kg}$ per nelayan per hari, maka secara kasar pendapatan kotor yang diperoleh nelayan berkisar Rp.50.000-75.000 per hari atau Rp.1.500.000-2.250.000 per bulan. Kawasan penangkapan ikan bilih terdapat di daerah Silintong (Silalahi I) dan di sekitar muara Sungai Bul-bul.

Berdasarkan pada rata-rata total hasil tangkapan ikan bilih yang dibeli oleh pedagang pengumpul di keempat tempat pendaratan tersebut, maka total hasil tangkapan per hari dapat diperkirakan 6,5 ton. Berdasarkan pada wawancara dengan nelayan diperoleh informasi bahwa hasil tangkapan ikan pada umumnya menurun sampai $50 \%$ pada saat bulan terang. Dalam hal ini, diasumsikan bahwa selama 15 hari bulan gelap dan 15 hari bulan terang, sehingga pada bulan gelap total hasil tangkapan ikan bilih 97,5 ton dan pada bulan terang 48,75 ton, sehingga total tangkapan dalam satu bulan 146,25 ton. Perkiraan total hasil tangkapan ikan bilih pada tahun 2008 adalah 1.755 ton (Tabel 2).

Perkiraan total hasil tangkapan pada tahun 2008 ini hampir tiga kali lipat lebih besar dibandingkan hasil tangkapan ikan pada tahun 2005 yang mencapai 653,6 ton. Nilai hasil tangkapan pada tahun 2008 mencapai Rp.5,265 milyar dengan rata-rata harga ikan bilih yang dijual ke pedagang pengumpul Rp.3.000/kg atau naik dari nilai hasil tangkapan ikan pada tahun 2005 yang mencapai Rp.3,9 milyar. Meskipun harga ikan pada tahun 2008 hanya separuh dari harga ikan pada tahun 2005( Rp.6.000 per $\mathrm{kg})$

Total hasil tangkapan ikan di Danau Toba pada tahun 2005 mencapai 4.462,2 ton yang didominasi oleh ikan mujahir $(25,3 \%)$, nila $(25,3 \%)$, dan bilih $(14,6 \%)$. Jika diasumsikan total hasil tangkapan ikan pada tahun 2008 sama dengan tahun 2005, maka hasil tangkapan ikan bilih akan mendominasi total hasil tangkapan (39,3\%). Berapa besar hasil tangkapan ikan bilih yang sebenarnya belum dapat diketahui, karena selama ini hasil tangkapan ikan bilih tidak pernah tercatat dalam data statistik di Dinas Perikanan.

Kontribusi ikan bilih juga terlihat dalam menu makanan di beberapa rumah makan dan restoran, baik yang terdapat di Parapat maupun di Pematang Siantar dan Medan yang disajikan dalam bentuk ikan goreng maupun ikan kuah. Ikan bilih yang dibawa ke Pekanbaru diolah menjadi ikan bilih kering yang dipasarkan ke beberapa daerah. Sejak awal bulan Juni 2008, 
pemasaran ikan bilih kering telah sampai ke daerah Ombilin di tepi Danau Singkarak. Berapa nilai kontribusi ikan bilih terhadap sosial ekonomi masyarakat perlu dikaji lebih lanjut, meskipun secara kualitatif nilai kontribusi tersebut mulai nampak secara nyata.

Ikan olahan dalam bentuk ikan kering juga pernah dilakukan, namun karena harga jual ikan kering tidak jauh berbeda dengan ikan segar, maka nelayan lebih memilih menjual ikan bilih dalam bentuk segar. Peluang pengembangan produk ikan bilih kering cukup besar terutama untuk mengisi pasar ekspor ke negara jiran (Malaysia dan Singapura) yang sejak tahun 2000 telah terhenti akibat tidak ada bahan baku ikan bilih yang selama ini dipasok dari Danau Singkarak.

\section{PENGELOLAAN SUMBER DAYA IKAN BILIH}

Pengelolaan perikanan adalah suatu proses yang dimulai dari pengumpulan dan analisis data, perumusan, dan penetapan peraturan, pengawasan dan pengendalian, monitoring dan evaluasi, serta penerapan dan pelaksanaannya. Tujuan dari pengelolaan perikanan tersebut adalah meningkatkan hasil tangkapan ikan sampai mendekati potensi alami dan sekaligus menjaga kelestariannya. Pola pengelolaan populasi ikan bilih di Danau Toba perlu segera dilakukan agar populasi dapat dieksploitasi secara optimal dan berkelanjutan. Tindakan pengelolaan yang penting segera diterapkan antara lain:

\section{Penetapan Suaka Perikanan}

Suaka perikanan untuk ikan bilih perlu ditetapkan di muara-muara sungai seperti Sungai Sipangolu di Bakara, Sungai Sipisopiso (Tongging), Sungai Sisodang (Tomok), dan Sungai Naborsahan (Ajibata) untuk melindungi ikan bilih yang memijah. Di muara-muara sungai tersebut penangkapan ikan bilih dilarang, terutama penangkapan ikan yang memotong atau menutup jalur ruaya pemijahan ikan bilih.

\section{Pengaturan Alat Tangkap}

Alat tangkap jaring insang yang digunakan tidak boleh mempunyai ukuran mata lebih kecil dari 1,25 inci. Hal ini dilakukan untuk memberikan kesempatan bagi ikan bilih mencapai dewasa dan melakukan pemijahan karena ikan bilih yang tertangkap dengan jaring ukuran mata kurang dari 1,25 inci pada umumnya belum matang kelamin. Jika alat tangkap yang digunakan adalah jala, maka ukuran ikan bilih yang tertangkap dengan ukuran panjang total lebih kecil dari $8 \mathrm{~cm}$ dilepaskan kembali.

\section{Pengembangan Penanganan Hasil Tangkapan}

Diverifikasi produk hasil tangkapan ikan bilih perlu dilakukan untuk meningkatkan nilai tambah produk dan pemasaran. Hasil tangkapan dapat diolah sendiri oleh masyarakat sekitarnya sehingga meningkatkan tenaga kerja dan pendapatan. Pengembangan pemasaran sebagai komoditas ekspor seperti yang pernah terjadi di Danau Singkarak perlu dilakukan.

\section{Pengembangan Kelembagaan Pengelolaan Perikanan}

Pembentukan kelembagaan pengelola perikanan perlu dilakukan, misalnya melalui pembentukan kelompok nelayan yang antara lain bertujuan untuk meningkatkan kapasitas dan kapabilitas nelayan dalam pengelolaan perikanan. Dampak yang dapat dipetik dari kegiatan ini antara lain adalah meningkatkan taraf hidup dan pendapatan 
nelayan. Penguatan kelompok nelayan juga dapat mengatasi permasalahan harga jual ikan bilih sehingga tidak dipermainkan tengkulak.

\section{Penetapan Peraturan Pengelolaan Perikanan}

Sampai saat ini peraturan pengelolaan perikanan, khususnya yang menyangkut pengelolaan populasi ikan bilih belum tersedia, maka untuk menjamin keberlanjutan hasil tangkapan dan sumber daya ikan bilih, peraturan pengelolaan segera ditetapkan. Oleh karena itu, secara administratif Danau Toba termasuk ke dalam 6 kabupaten, yaitu Simalungun, Toba Samosir, Humbang Hasunduta, Samosir, Dairi, dan Karo, maka Peraturan Daerah yang ditetapkan di tingkat Propinsi Sumatera Utara, sedangkan Peraturan Daerah di tingkat kabupaten mengacu ke Peraturan Daerah propinsi sehingga setiap kabupaten akan mempunyai aturan yang sama.

\section{Pengembangan Pengelolaan Perikanan secara Bersama}

Pembagian kekuasaan antara masyarakat dan pemerintah dalam pengelolaan perikanan di Danau Toba perlu dikembangkan dengan lebih baik sehingga terbentuk pola pengelolaan perikanan secara bersama (fisheries comanagement). Dalam hal ini, pembentukan kelembagaan pengelolaan perikanan merupakan hal yang mutlak seperti yang disarankan di Danau Singkarak (Koeshendrajana et al., 2005). Pemerintah daerah sebagai otoritas pengelola perairan umum, dalam hal ini Danau Toba akan memegang kunci keberhasilan pengembangan perikanan di perairan tersebut.

\section{Monitoring dan Evaluasi}

Monitoring tangkapan ikan bilih yang meliputi total tangkapan, ukuran ikan yang tertangkap, jumlah dan jenis alat tangkap, jumlah trip penangkapan, daerah penangkapan, dan pemasaran perlu dilakukan. Data dan informasi ini sangat penting untuk mengevaluasi tindakan pengelolaan perikanan yang berlangsung dan sebagai dasar untuk memperbaiki pengelolaan pada tahun berikutnya.

\section{PROSPEK PERIKANAN IKAN BILIH}

Mempertimbangkan perkembangan populasi ikan bilih yang cepat dan kondisi lingkungan Danau Toba yang sangat sesuai bagi perkembangannya, maka pada tahun selanjutnya hasil tangkapan ikan bilih diprakirakan akan mendominasi total hasil tangkapan ikan di danau ini. Berdasarkan nilai produktivitas primer perairan, potensi produksi ikan di Danau Toba ditaksir mencapai 7.309 ton per tahun. Pada tahun 2005, total produksi tangkapan ikan mencapai 4.462,2 ton dan produksi tangkapan ikan bilih adalah 653,6 ton. Dengan asumsi produksi tangkapan ikan lainnya stagnan, maka produksi tangkapan ikan bilih diperkirakan dapat mencapai 3.000 ton per tahun. Bandingkan dengan produksi tangkapan ikan bilih di Danau Singkarak yang hanya mencapai sekitar 378 ton pada tahun 2003. Perkiraan produksi tangkapan ikan bilih di Danau Toba tersebut diharapkan dapat menghidupkan kembali nelayan yang pada tahun 2005 berjumlah sekitar 2.200 RTP (Rumah Tangga Perikanan).

Untuk mengantisipasi hasil tangkapan yang meningkat dan kemungkinan harga jual yang menurun, maka dapat dilakukan upaya pengolahan ikan bilih menjadi 
komoditas ekspor, seperti yang pernah terjadi di Danau Singkarak. Dalam hal ini, pelatihan terhadap masyarakat tentang cara pengolahan ikan yang baik perlu dilakukan. Apabila hal ini dapat terlaksana, maka dampak ganda (multiplier effects) dari kegiatan ini akan terjadi, setidaknya dalam peningkatan penyerapan tenaga kerja, peningkatan pendapatan nelayan dan masyarakat perikanan khususnya, serta peningkatan pendapatan asli daerah.

Ikan bilih juga dapat dijadikan kandidat ikan introduksi bagi danau-danau yang mempunyai karakteristik limnologis hampir sama dengan Danau Toba atau Singkarak, terutama danau-danau yang berada di dataran tinggi, seperti Danau Diatas dan Danau Dibawah (Sumatera Barat), Danau Kerinci (Jambi), Danau Ranau (Sumtera Selatan), Danau-danau di Kompleks Malili (Sulawesi), serta danau-danau di Papua dan Irian Jaya Barat. Dalam pelaksanaan introduksi ikan bilih tersebut perlu didahului dengan riset secara seksama dan dibuatkan protokol penebaran sehingga tidak menimbulkan dampak negatif terhadap populasi ikan asli. Pendekatan introduksi ikan bilih tersebut dilakukan dengan pendekatan kehati-hatian, apalagi di danau-danau daerah Sulawesi, Papua, dan Irian Jaya Barat dihuni oleh jenis-jenis ikan endemik yang rentan terhadap gangguan dan perubahan ekosistem sehingga populasi mudah menurun dan punah.

\section{KESIMPULAN DAN REKOMENDASI}

1. Populasi ikan bilih yang melimpah di Danau Toba merupakan salah satu contoh keberhasilan introduksi ikan yang dilandasi hasil kajian ilmiah yang memadai. Di samping juga, merupakan salah satu upaya penyelamatan populasi ikan bilih di luar habitat aslinya, Danau
Singkarak dari eksploitasi yang intensif sehingga mengancam kelestariannya.

2. Belajar dari pengalaman eksploitasi stok ikan bilih di Danau Singkarak yang tidak terkendali, upaya pengelolalan perikanan, khususnya populasi ikan bilih di Danau Toba perlu segera diterapkan untuk menjamin kesinambungan produksi dan kelestarian sumber daya ikan. Tekhnik pengelolaan yang perlu diterapkan antara lain meliputi penetapan suaka perikanan, pengaturan alat tangkap, penanganan hasil tangkapan, pengembangan kelembagaan dan peraturan pengelolaan, pengembangan pengelolaan secara bersama dan monitoring, serta evaluasi. Di masa yang akan datang, kontribusi perikanan ikan bilih terhadap kehidupan dan perekonomian masyarakat diperkirakan akan semakin besar dan nyata.

3. Ikan bilih dapat dijadikan sebagai kandidat ikan tebaran di danau dengan karakteristik limnologis yang sama seperti Danau Singkarak atau Danau Toba.

\section{DAFTAR PUSTAKA}

Cowx, I. G. 1994. Stocking strategy. Fisheries Management and Ecology. (1): 15-30.

Cowx, I. G. 1999. An appraisal of stocking strategies in the light of developing country constraints. Fisheries Management and Ecology. (6): 21-34.

Kartamihardja, E. S. 1993. Potensi produksi ikan dan pengelolaan perikanan di Danau Toba, Sumatera Utara. Buletin Penelitian Perikanan Darat. 6 (1): 10-15. 
Kartamihardja, E. S. \&A. S. Sarnita. 2008 (in press). Populasi Ikan Bilih di Danau Toba: Keberhasilan Introduksi Ikan, Pengelolaan, dan Prospek Masa Depan. Pusat Riset Perikanan Tangkap. Badan Riset Kelautan dan Perikanan. Departemen Kelautan dan Perikanan. 63 pp.

Kartamihardja, E. S. \& K. Purnomo. 2006. Penyelamatan populasi ikan bilih (Mystacoleucus padangensis) ke habitatnya yang baru di Danau Toba. Demersal dari Laut untuk Pembangunan. Edisi Maret 2006.

Kottelat, M., A. J. Whitten, S. N. Kartikasari, \& S. Wirjoatmodjo. 1993. Freshwater Fishes of Western Indonesia and Sulawesi. Periplus Editions. Hong Kong. $221 \mathrm{pp}$.

Koeshendrajana, S., K. Purnomo, \& E. S. Kartamihardja. 2005. Permasalahan dan alternatif solusi pemacuan stok ikan bilih (Mystacoleucus padangensis) di Danau Singkarak, Sumatera Barat (Kajian Sosial Ekonomi dan Kelembagaan). Jurnal Penelitian Perikanan Indonesia, Edisi Sosial Ekonomi. 11(3): 2005. 5164.

Purnomo, K., C. Umar, S. Nuroniah, Krismono, \& A. S. Nastiti. 1992. Penelitian tata ruang usaha perikanan di Danau Singkarak, Sumatera Barat. Laporan Penelitian 1991/1992. Sub Balai
Penelitian Perikanan Air Tawar. Balai Penelitian Perikanan Air Tawar. Sukamandi. 18 pp.

Purnomo, K., E. S. Kartamihardja, \& S. Koeshendrajana. 2003. Pemacuan stok ikan di Danau Singkarak (Sumatera Barat) dan Sungai Batanghari (Jambi). Laporan Hasil Penelitian Tahun 2002. Pusat Riset Perikanan Tangkap. Badan Riset Kelautan dan Perikanan. Departemen Kelautan dan Perikanan. Jakarta. 16 pp.

Purnomo, K., E. S. Kartamihardja, Wijopriono, Z. Fahmi, M. M. Wahyono, R. Faizah, \& A. S. Sarnita. 2005. Riset pemetaan kapasitas sumber daya ikan dan lingkungan di Danau Toba, Sumatera Utara. Laporan Teknis Hasil Penelitian Tahun 2005. Pusat Riset Perikanan Tangkap. Badan Riset Kelautan dan Perikanan. Departemen Kelautan dan Perikanan. Jakarta.

Purnomo, K., E. S. Kartamihardja, \& S. Koeshendrajana. 2006. Upaya pemacuan stok ikan bilih (Mystacoleucus padangensis) di Danau Singkarak. Prosiding Seminar Nasional Ikan IV. Kerja Sama antara MMI, Loka Riset Pemacuan Stok Ikan-Departemen Kelautan dan Perikanan, Departemen MSP-Institut Pertanian Bogor, dan Pusat Penelitian Biologi-Lembaga IImu Pengetahuan Indonesia. 